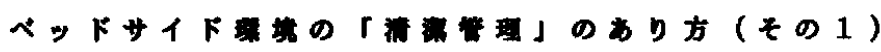

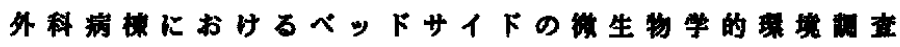

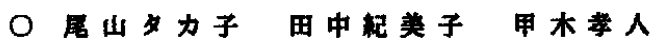

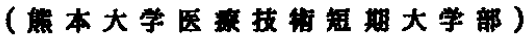

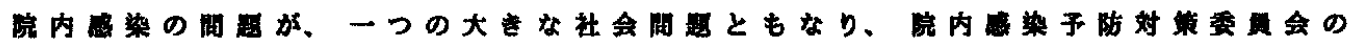
即やインフェクションコントロールナース盖成の必要性がいわれはしめた。この

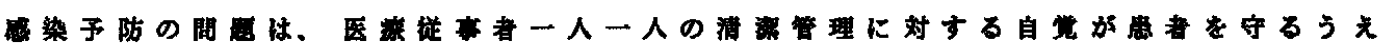

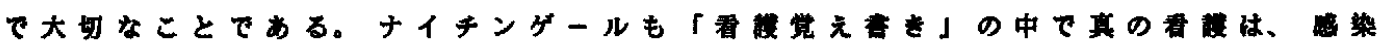

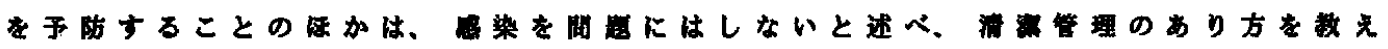

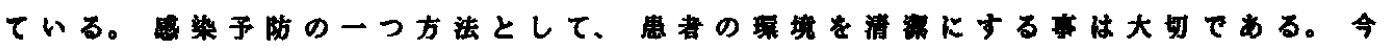
回、私たちが日常行っているへッドサイドケアが、架予防のうえてとのような意

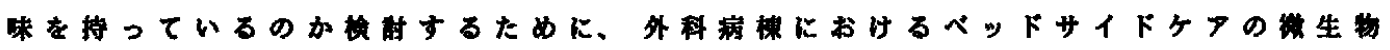
学的境境章を行った。

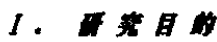

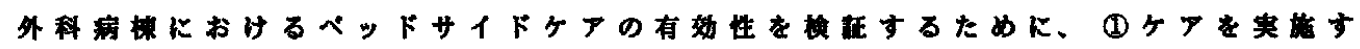

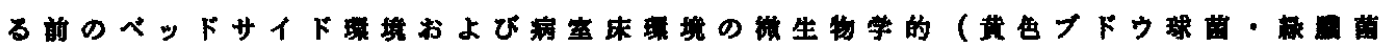

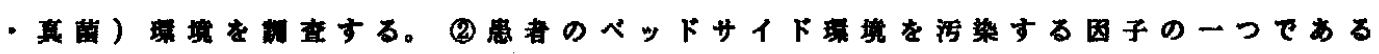

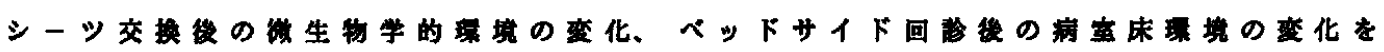

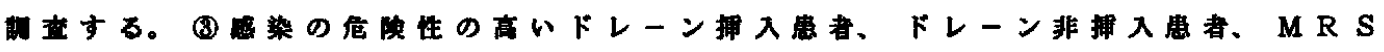

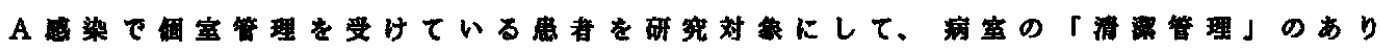
方を明龍にする。

\section{I. 第方运}

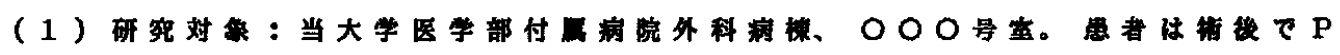

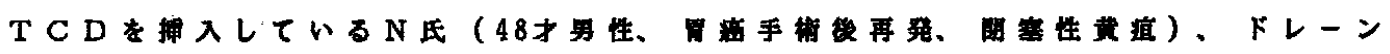

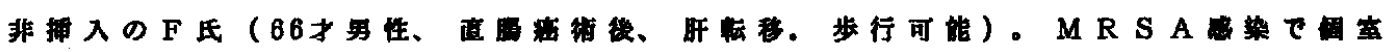
管理を受けているY氏（66オ男性、胃雪性リンパ国、スキルス）の○○○易至。

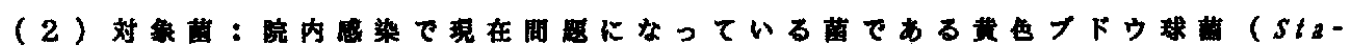

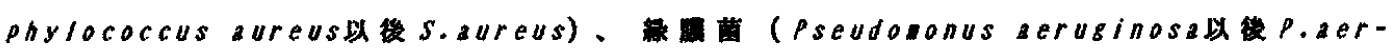
uginosa) 、真苗 (Candida albicans以後C.albicans) の三萑とした。

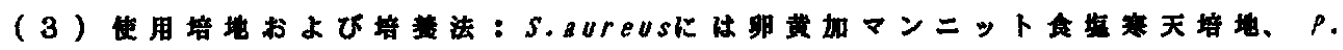

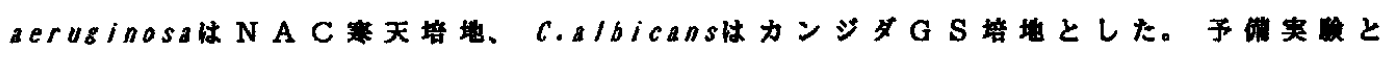

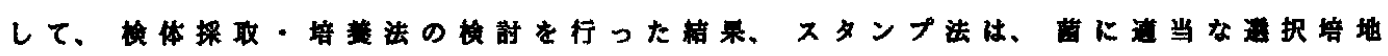
を使用することて、採取と分铛を同時に行うことがでることがわかった。そこで、 培地は、面径 $35 \mathrm{mn}(9.6 \mathrm{~cm})$ シャーレに培地面がわずかにシャーレの䜌より亮くな るように分注した物をつくりスタンプ法で苗が探取しやすいようにした。

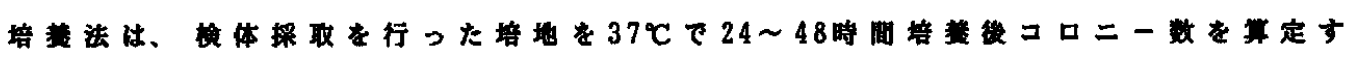

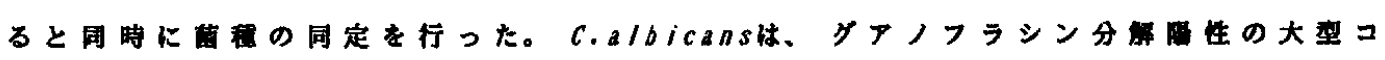

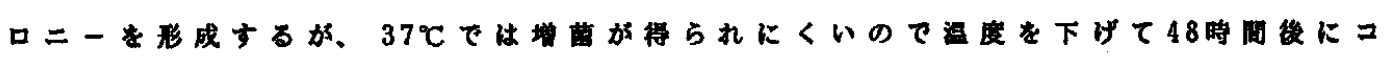




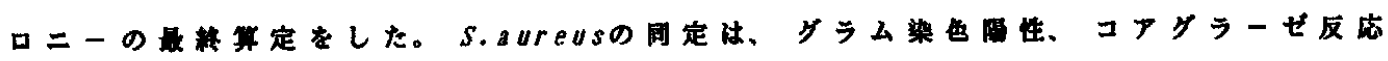

但でってs.aureusと同定した。

（4）体採取及び探取部位：シーツ交换が

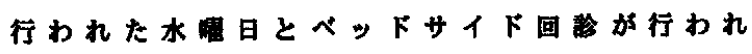
た土回白の2 日间。採取部位林（图1）に示

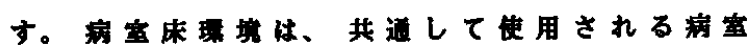
スり口、洗面所床、扇室中央部で取した。

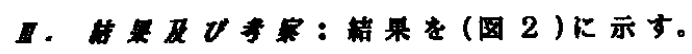

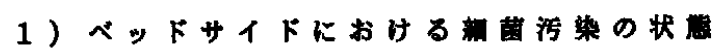

患者のシーッ上、ベット势加らC.albicans、

P.aeruginosa、s.aureusが检出された。

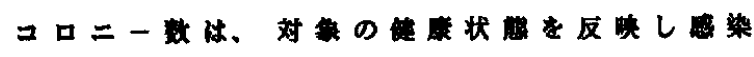
主费者 $\mathrm{Y}$ 氏>ドレーン搏入者 $\mathrm{N}$ 氏>ドレーン

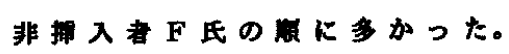

ペッド模・ベッド周辺床のコロニー效は、 ベッド上のコロニー数が反眏している。

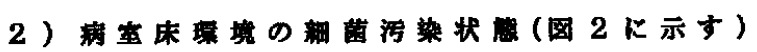

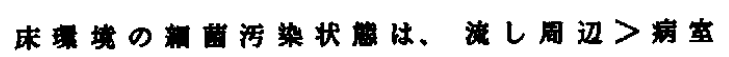
中央>扁入り口付近の眼にコロニーが多かっ た。分部された曾には、S.aureus,C.albicans が台まれていた。患者がベッドの年障に利用す

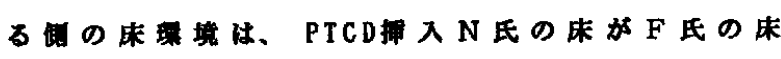
よりコロニー数が多かた。MRSAで成管 理されている $\mathrm{Y}$ 氏証床不可能でりながら 氏より机めて象くのコロニー数加分浽された。

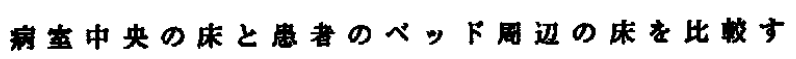
ると、F氏の合㹥コロニー数に差はみられな いが、N氏の合性ベット周辺林の方が多かっ た。

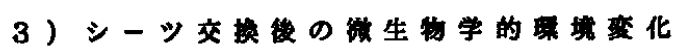

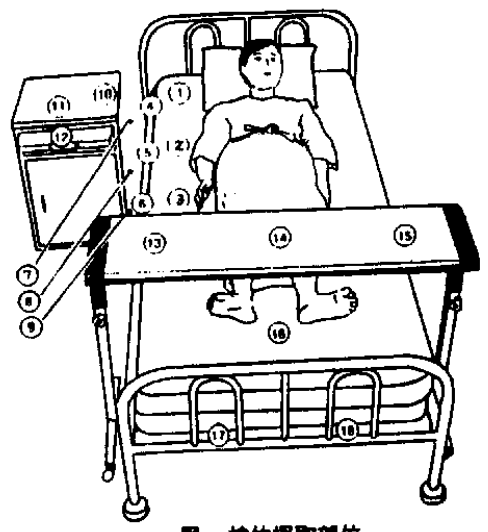

因楼体挥取郎位

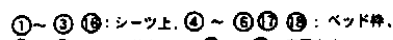

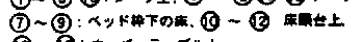

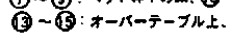

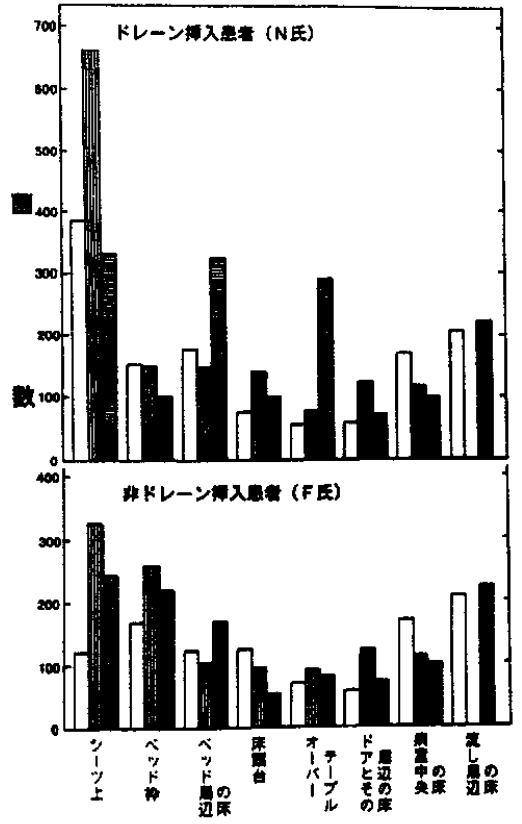

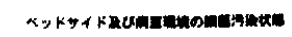

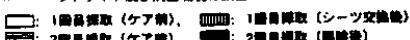

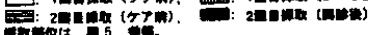

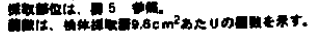

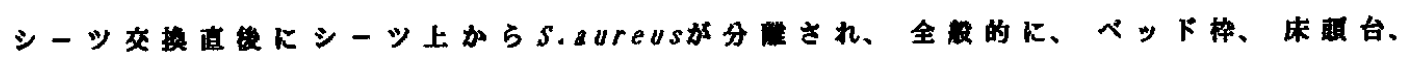
オーバーテーブルともにコロニー数が增加していた。きれいにするはすのシーッ交

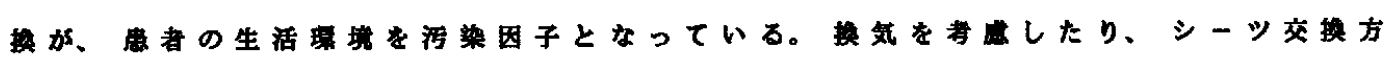

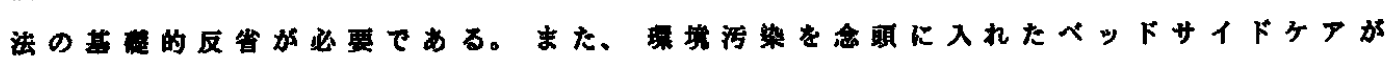
必要である。

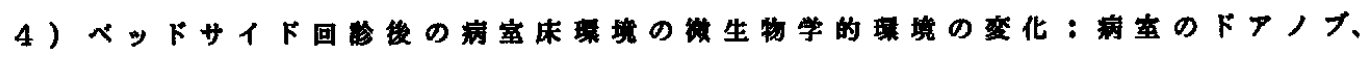

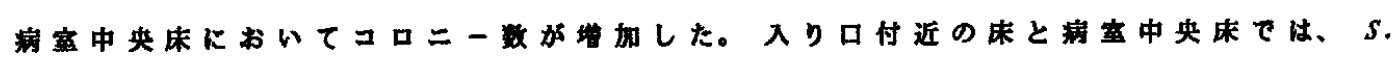

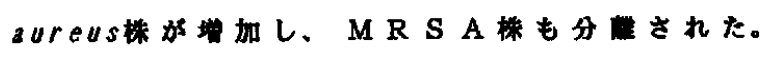

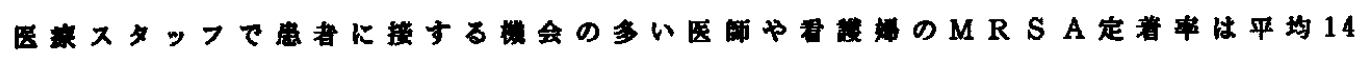

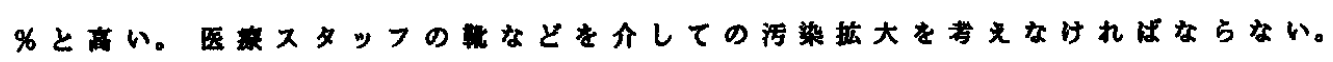

